\title{
Soil-landscape model helps predict potassium supply in vineyards
}

\author{
by Anthony T. O'Geen, Stuart Pettygrove, \\ Randal Southard, Hideomi Minoshima \\ and Paul S. Verdegaal
}

The Lodi Winegrape District is one of the largest in California and encompasses a wide diversity of wine-grape varieties, production systems and soils, which complicates grape nutrient management. To identify regions within this district that have similar nutrient-management needs, we are developing a soil-landscape model based on soil survey information. Our current model identifies five regions within the Lodi district with presumed relationships between soil properties and potassium-supplying ability. Region 1 has weakly developed, clay-rich soils in basin alluvium; region 2 has weakly developed, coarser-textured soils on recent alluvial fans, flood plains and stream terraces; region 3 has moderately developed soils on low terraces derived from granitic alluvium; region 4 has highly developed soils on high terraces derived from mixed alluvium; and region 5 has weakly developed soils formed on undulating volcanic terrain. Field and lab studies of soils in these regions show that our model is reasonable in concept, but that it must be fine-tuned to account for differing degrees of soil variability within each region in order to make realistic nutrient-management predictions.

T he Lodi Winegrape District is one of the largest in California, with approximately 750 growers and about 100,000 acres in production in San Joaquin and Sacramento counties. This district encompasses a wide range of wine-grape varieties, production systems and soils.

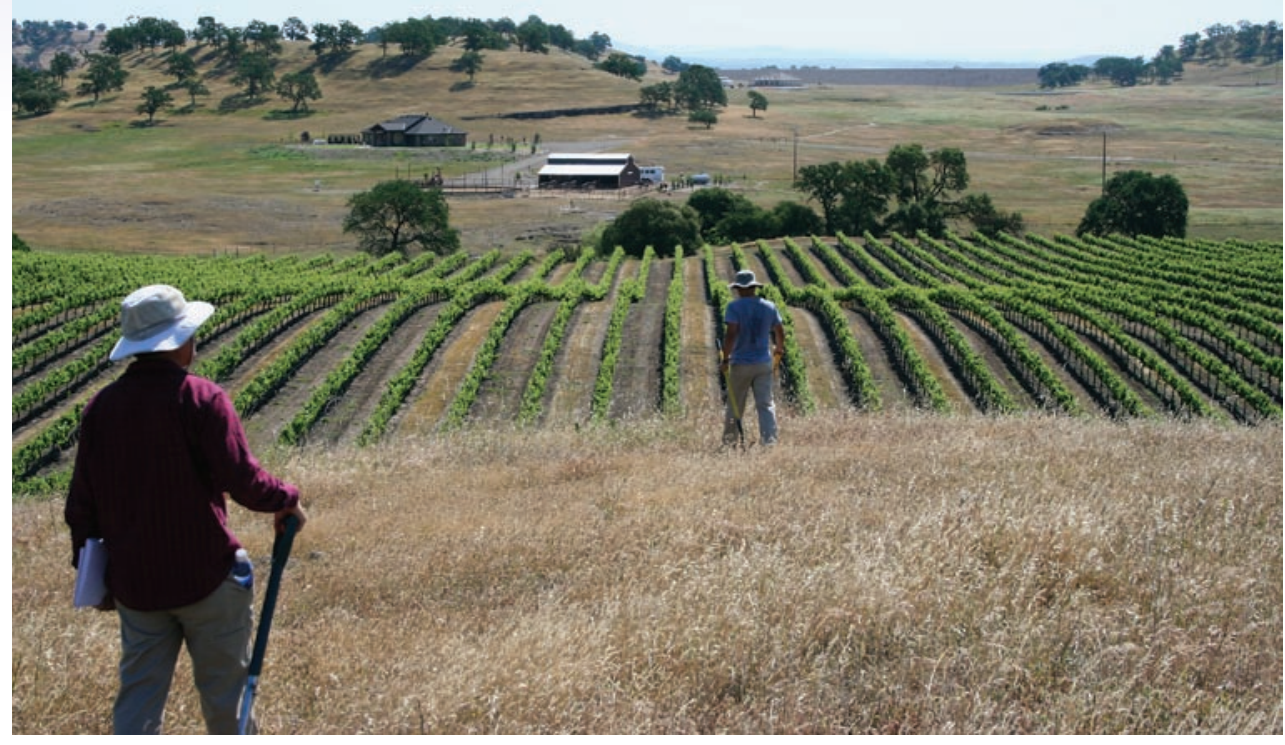

The Lodi Winegrape District of San Joaquin and Sacramento counties encompasses a wide range of soil types, on which about 100,000 acres of wine grapes are grown.

Many growers and crop management professionals in this district and elsewhere in California lack confidence in some of the grape nutrientmanagement guidelines developed by the University of California over the past few decades (Christensen et al. 1978). These guidelines were based largely on research conducted with own-rooted, flood-irrigated 'Thompson Seedless' grapes. Several factors may contribute to the limitations of existing UC nutrient guidelines, but in the Lodi Winegrape District, soil variability appears to be especially relevant.

This district has an incredible diversity of soils that encompass a range of ages, parent mineralogy and physical properties possibly found in no other agricultural area of similar size in the United States. This variability reflects the presence - even within single vineyards - of a mélange of volcanic, metamorphic and granitic alluvial and upland landforms spanning a range of ages, from modern-day stream deposits to ancient geomorphic surfaces among the oldest in the country.

In such an environment, a single set of soil and nutrient management practices cannot reasonably be expected to meet wine-grape yield and quality goals. In particular, it is well known that the chemical and physical properties of soil control a plant's supply of potassium (K)

\section{Potassium and wine grapes}

Potassium is an essential nutrient for plant growth and is needed in relatively large amounts by many crops. In grapes, potassium deficiency results in reduced vine growth, premature leaf drop and yield loss (Christensen et al. 1978). During periods of rapid leaf and fruit growth, the rate of potassium uptake by the fruit is high.

Care must be taken not to overapply potassium fertilizers. High levels in the soil can contribute to excess potassium in red grape skins, reducing color. The intensity of wine color is an important sensory component of wine. Excessive potassium uptake by grapes can also lead to an increase in juice $\mathrm{pH}$ (Boulton 1980) and a decrease in the yeast-assimilable nitrogen and ammonia of the fruit (Wehmeier 2002). Excess potassium in the wine may precipitate as potassium tartrate during cold stabilization, requiring the winery to adjust $\mathrm{pH}$ to avoid losing an important sensory component of the wine. Undesirably high potassium levels are a documented problem in some Australian vineyard soils (Krstic et al. 2003). 


\section{Glossary}

Cation exchange capacity

(CEC): The sum total of exchangeable, positively charged ions that a soil can adsorb and then release to soil solution. Cation exchange sites serve as a reservoir of plant-available nutrients such as potassium. CEC differs based on the magnitude of negative charge on the minerals, surface area, the nature of the silicate layering and soil organic matter content.

Duripan: A silica-cemented soil layer, also referred to as a hardpan.

Exchangeable potassium: Potassium on cation exchange sites that can be extracted by ammonium acetate.

Horizon: A layer of soil formed parallel to the soil surface and affected by soil-forming processes.

Iron oxides: A group of minerals (e.g., hematite, goethite, ferrihydrite) that impart reddish color in soils, with very low $\mathrm{CEC}$ and no potassium fixation potential.

Lithology: The description of rocks on the basis of their physical and chemical characteristics.

Mineralogy: The description of the assemblage of primary and secondary minerals in soil.

Potassium fixation: The adsorption of potassium from soil solution into the crystalline structure of minerals, such as vermiculite, which makes the potassium less available for plant uptake.

Smectite: A layer-silicate clay with lower negative charge than vermiculite; has high shrink-swell capacity and high CEC, but low potassiumfixation potential.

Soil taxonomy: The classification of soil bodies into a hierarchy of groups based on measured soil properties.

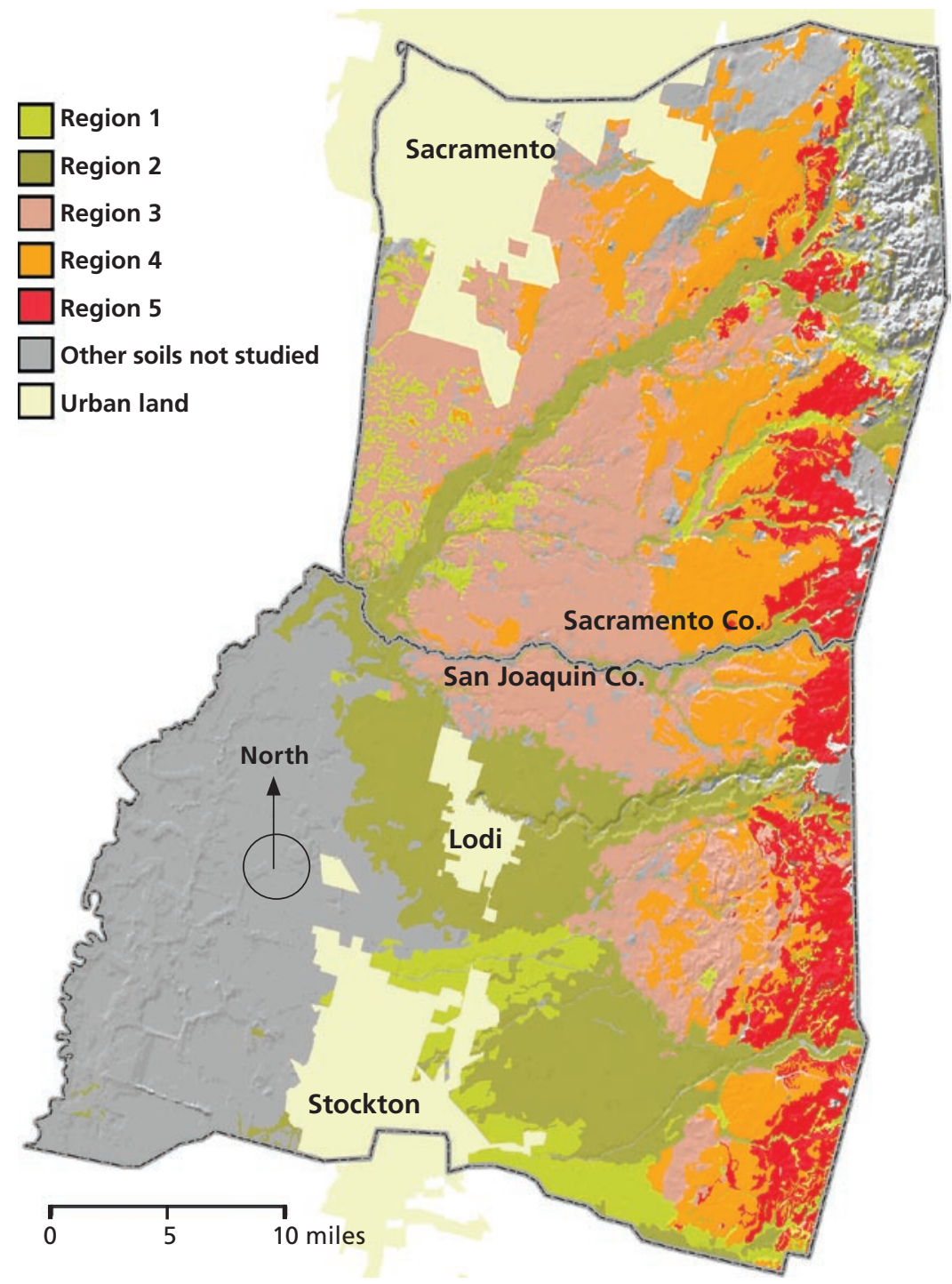

Fig. 1. Modeled soil regions in the Lodi Winegrape District.

\section{Soil controls potassium supply}

Plant-available potassium occurs in the soil solution or as exchangeable cations on soil mineral particles and organic matter. Over time, potassium can leach from soils, especially sandy ones, and must be replaced by either fertilization or the slow-release weathering of minerals.

Potassium fixation. Potassium fixation is an important phenomenon in soils derived from granitic parent material. Potassium gets trapped within the crystalline structure of vermiculite (a layer-silicate mineral derived from mica) and becomes less available to plants. Soils with vermiculite are common in granitic alluvium on the east side of the Central Valley, especially in landscapes with moderately weathered soils. Potassium fixation is influ- enced by soil mineralogy and texture (Murashkina et al. 2007a, 2007b).

Vermiculite is a transitory mineral in most soils. As soils develop, parent materials weather from primary minerals, such as mica, into secondary minerals, such as vermiculite and smectite. In turn, these secondary minerals can be further weathered into new minerals such as kaolinite and iron oxides.

Each mineral has intrinsic differences in the magnitude of potassium fixation and cation exchange capacity (CEC). Micas have low potassium-fixation and low cation exchange capacity; vermiculite has high potassium-fixation and high cation exchange capacity; smectite has low potassium-fixation and high cation exchange capacity; and kaolinite and iron oxides have low potassiumfixation and low cation exchange capacity. 


\begin{tabular}{|c|c|c|c|c|c|}
\hline Soilscape characteristics & Geologic age of parent material* & $\begin{array}{l}\text { K-rich } \\
\text { weatherable } \\
\text { mineralst }\end{array}$ & $\begin{array}{l}\text { Soil } \\
\text { weathering } \\
\text { intensityt }\end{array}$ & $\begin{array}{l}\text { Exchangeable } \\
\text { K‡ }\end{array}$ & $\begin{array}{l}\text { K fixation } \\
\text { potentialł }\end{array}$ \\
\hline \multicolumn{6}{|c|}{ years } \\
\hline Region 1: Alluvial fans, fine-textured & $\begin{array}{l}0-14,000 \text { (post-Modesto and } \\
\text { upper Modesto formations) }\end{array}$ & Moderate & Low & High & None \\
\hline $\begin{array}{l}\text { Region 2: Alluvial fans, coarse-textured, } \\
\text { granitic alluvium }\end{array}$ & $\begin{array}{l}0-70,000 \text { (post-Modesto } \\
\text { and Modesto formations) }\end{array}$ & High & Low & Moderate & Moderate \\
\hline $\begin{array}{l}\text { Region 3: Low terraces, duripans, granitic } \\
\text { alluvium }\end{array}$ & $\begin{array}{l}130,000-330,000 \\
\text { (Riverbank formation) }\end{array}$ & Moderate & Moderate & Low & High \\
\hline Region 4: High terraces, mixed alluvium & $\begin{array}{l}>600,000 \text { (Turlock Lake } \\
\text { and Laguna formations) }\end{array}$ & Low & High & Moderate & None \\
\hline Region 5: Undulating volcanic terrain & 3-10 million (Mehrten formation) & High & Low & High & None \\
\hline \multicolumn{6}{|c|}{$\begin{array}{l}\text { * Geologic ages based on Marchand and Allwardt (1981). } \\
\text { + Weatherable minerals and soil weathering intensity classes are not quantitative, but reflect relative differences based on soil properties. } \\
\text { ₹ Exchangeable K and K fixation classes are based on profile-weighted averages for each representative soil. Exchangeable K (mg/kg): } \\
\text { high }>200 \text {, moderate } 100-200 \text {, low }<100 \text {. Class cutoffs for K fixation potential (mg/kg): High }>100 \text {, moderate } 0-100 \text {, none }<0 \text {. }\end{array}$} \\
\hline
\end{tabular}

Soil-specific potassium fertilization. Current recommendations for potassium fertilization in California vineyards do not take into account potential differences among soils in fertilizer effectiveness or the maintenance of soluble potassium levels (Christensen et al. 1978).

We propose that the key characteristics of soils that control potassium supply and retention, while not explicitly a part of the soil classification system, can be inferred from soil-survey database information. Rather than providing a regionwide prescription for potassium nutrition, our goal was to develop a landscape-targeted model that predicts the fate of potassium, based on properties of the soil parent material and the degree of soil development.

\section{Lodi soils}

The Lodi Winegrape District is located at the confluence of the San Joaquin and Sacramento rivers immediately east of the San JoaquinSacramento Delta and west of the lower Sierra Foothills. The average vineyard size is approximately 80 acres, usually in multiple small parcels. The district's principal wine-grape varieties are Zinfandel (comprising $40 \%$ of California's total acres), Chardonnay, Cabernet Sauvignon, Sauvignon Blanc, Merlot and Syrah.

Soils of the Lodi district vary spatially as a result of the parent materials' depositional history and subsequent weathering. Soils on the east side of the San Joaquin Valley formed from alluvium (sediment transported by water) that accumulated over thousands to millions of years from erosion of the Sierra Nevada. As a result, the district's soils fall into a systematic spatial pattern: the youngest materials are generally on the west side, the oldest are generally on the east side, and materials of intermediate age are in the center.

Through time, the source material of this terrain has changed. During the initial stages of Sierran uplift, the mountains were capped with metamorphosed sedimentary rock, metamorphosed volcanic rock and volcanic rock. As the uplift continued, the mountain caps were stripped by erosion, exposing the granitic rocks that lay beneath. The lithology and age of parent materials in which the soils formed have changed over time, resulting in a variety of soil mineral assemblages.

\section{Soil-landscape model}

Potassium fertilizer requirements are determined by the balance between plant demands for this nutrient and the capacity of the soil to provide it. Our model encompasses three factors: (1) the slow release of potassium by mineral weathering, which determines total potassium supply; (2) the soil's cation exchange capacity, which affects the retention of available potassium; and (3) the soil's potassium fixation potential, which reduces the availability of exchangeable potassium.

The primary datasets for our model were the Soil Survey Geographic databases (SSURGO) for Sacramento and San Joaquin counties. (To view an example of soil survey information see Web Soil Survey at http://soils.usda.gov or Online Soil Survey http://casoilresource.lawr. ucdavis.edu/soilsurvey). In a geographic information system (GIS), attribute tables containing taxonomic information for the dominant soil series of each soil map unit were joined to the soil maps (fig. 1, table 1). The hierarchical framework of soil taxonomy was used to define the degree of soil development and type of parent material (Soil Survey Staff 1999). Each regional soilscape consisted of aggregated soil map units through queries of SSURGO data.

The model groups soils into five regions with differences in parent material and degree of soil development, which serve as a proxy for potassium supply (table 1).

Region 1. This region has weakly developed, smectitic, clay-rich soils with high shrink-swell capacity in basin alluvium. We queried SSURGO for all soils classified as Vertisols and all in the smectitic soil mineralogy family class (Soil Survey Staff 1999).

Region 2. Region 2 has weakly developed, coarse- and loamy-textured soils on recent alluvial fans, flood plains and stream terraces. This region represents such soils formed mostly from granitic alluvium in their initial development stages. First, all weakly developed soils were queried as inferred by their taxonomic classification. We selected all Xerolls at the suborder level of soil taxonomy, and all Xerofluvents and Xeropsamments at the great group level (Soil Survey Staff 1999). These soils contain a broad mix of minerals. This initial query reflected soils developed in recent alluvium from freshly eroded Sierra materials. Some Xerolls are derived from the erosion of old volcanic terraces in the valley's eastern margins, 
but these soils were removed from the query by excluding the Pentz and the Peters soil series, which occur exclusively on volcanic terrain.

Region 3. Region 3 has moderately developed soils on low terraces derived from granitic alluvium. Region 3 was created from an initial query of all soils formed on low and high terraces that included Durixerepts, Palexeralfs and Durixeralfs at the great group level of soil taxonomy. This query identified all intermediate and well-developed soils in the district. From this query we selected soil map units that were dominated by soils formed on low terraces (San Joaquin or Bruella), and then also included soils found in valley positions of the oldest and highest alluvial terraces (Montpellier and Yellowlark) that are derived from granitic sources but were not in the original query.

Region 4. Region 4 has highly developed soils on old, high terraces derived from older, mixed alluvium (granitic, metamorphosed sedimentary and metamorphosed volcanic rock). These soils were selected from the same original query we used for region 3. From that original query, we excluded map units with dominant soil components of San Joaquin and Bruella.

The main difference between regions 3 and 4 is that region 3 soils are derived from granitic alluvium, which contain micas that weather to vermiculite, whereas region 4 soils are derived from older alluvium of mixed rock sources, which weather to mostly kaolinite and iron oxides.
Region 5. Region 5 has weakly developed soils formed on undulating volcanic terrain. Soils were identified through a query of the dominant soil series that occur exclusively on this parent material, including Pentz, Peters, Pardee and Keys. All map unit names that contained these soil series as the dominant soil were selected.

\section{Characterizing the soil regions}

Following preliminary fieldwork to assess soil variations within these five regions, several soil profiles in each region were sampled and analyzed. We then selected one soil profile from each to represent our model. Standard soil-survey techniques characterized the morphologic, chemical and physical properties of soils. Potassium fixa-

\begin{tabular}{|c|c|c|c|c|c|c|c|c|c|c|}
\hline Horizon & Depth & Color* & Sand & Silt & Clay & Clay mineralogyt & $\mathrm{pH}$ & CEC & Exchangeable $\mathrm{K}$ & K fixation \\
\hline & inches & moist soil & $\cdots$ & $\ldots \%$ & 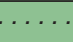 & & & $\mathrm{cmol}(+) / \mathrm{kg}$ soilf & $\ldots \ldots m g / k g s$ & il ...... \\
\hline \multicolumn{11}{|l|}{ Region 1} \\
\hline Ap & $0-5$ & 10YR 3/1 & 19 & 37 & 44 & $\mathrm{~S}, \mathrm{M}, \mathrm{K}$ & 6.2 & 29.1 & 631 & 0 \\
\hline Btss1 & $5-15$ & 10YR 2/1 & 16 & 37 & 47 & $\mathrm{~S}, \mathrm{~V}, \mathrm{~K}$ & 6.3 & 27.8 & 207 & 96 \\
\hline Btss2 & $15-24$ & 10YR 2/1 & 15 & 39 & 46 & $\mathrm{~S}, \mathrm{~V}, \mathrm{~K}$ & 6.3 & 28.4 & 211 & 277 \\
\hline $2 B C$ & $24-43$ & 7.5YR $3 / 3$ & 32 & 38 & 30 & $\mathrm{~S}, \mathrm{~V}, \mathrm{~K}$ & 6.4 & 17.6 & 92 & 467 \\
\hline \multicolumn{11}{|l|}{ Region 2} \\
\hline Ap & $0-5$ & 10YR 3/2 & 62 & 29 & 9 & $\mathrm{M}, \mathrm{K}$ & 5.6 & 7.1 & 233 & 0 \\
\hline$A$ & $5-17$ & 10YR $3 / 3$ & 61 & 29 & 10 & $\mathrm{M}, \mathrm{K}$ & 5.7 & 4.8 & 146 & 0 \\
\hline$A B$ & $17-23$ & 10YR 4/3 & 59 & 29 & 12 & $\mathrm{M}, \mathrm{K}$ & 6.0 & 5.8 & 110 & 0 \\
\hline Bt1 & $23-34$ & 10YR 4/3 & 61 & 27 & 12 & $\mathrm{M}, \mathrm{K}$ & 6.0 & 5.4 & 99 & 0 \\
\hline $\mathrm{Bt} 2$ & $34-41$ & 10YR 4/3.5 & 63 & 26 & 11 & $\mathrm{M}, \mathrm{V}, \mathrm{K}$ & 6.0 & 4.5 & 72 & 87 \\
\hline $\mathrm{C}$ & $41-47$ & 10YR 4/3 & 60 & 28 & 12 & $\mathrm{M}, \mathrm{V}, \mathrm{K}$ & 6.0 & 5.9 & 49 & 425 \\
\hline \multicolumn{11}{|l|}{ Region 3} \\
\hline Ap & $0-6$ & 7.5YR 3/4 & 49 & 26 & 25 & $\mathrm{M}, \mathrm{K}$ & 6.1 & 6.9 & 110 & 72 \\
\hline BA & $6-12$ & 5YR 3/4 & 49 & 24 & 27 & nd & 6.4 & 6.2 & 186 & 112 \\
\hline Bt1 & $12-23$ & 5YR 3/4 & 51 & 20 & 29 & nd & 6.5 & 6.2 & 182 & 67 \\
\hline Bt2 & $23-33$ & 5YR $3 / 4$ & 54 & 19 & 27 & nd & 7.0 & 6.2 & 165 & 160 \\
\hline $\mathrm{Bt3}$ & $33-37$ & 5YR 4/4 & 49 & 19 & 32 & nd & 6.9 & 8.5 & 33 & 129 \\
\hline Btqm & $37-55$ & 7.5YR 4/4 & 61 & 26 & 13 & $\mathrm{~V}, \mathrm{~K}, \mathrm{M}$ & 6.7 & 8.3 & 21 & 230 \\
\hline $2 B C$ & $55-72$ & 7.5YR 4/4 & 64 & 20 & 16 & nd & 6.6 & 6.1 & 22 & 268 \\
\hline \multicolumn{11}{|l|}{ Region 4} \\
\hline Ap1 & $0-6$ & $5 Y R \quad 4 / 4$ & 38 & 33 & 29 & $\mathrm{~K}, \mathrm{M}(\mathrm{tr})$ & 6.0 & 11.5 & 384 & 0 \\
\hline $\mathrm{A} / \mathrm{Bt}$ & $6-24$ & 5YR 4/4 \& 2.5YR 3/6 & 36 & 30 & 34 & $\mathrm{~K}, \mathrm{M}(\mathrm{tr})$ & 4.2 & 6.8 & 213 & 0 \\
\hline Bt1 & $24-38$ & $2.5 Y R \quad 4 / 4$ & 59 & 16 & 25 & $\mathrm{~K}, \mathrm{M}, \mathrm{V}(\mathrm{tr})$ & 3.9 & 11.6 & 110 & 0 \\
\hline Bt2 & $38-42$ & $2.5 Y R$ 4/6 & 32 & 20 & 48 & $\mathrm{~K}, \mathrm{M}, \mathrm{V}(\mathrm{tr})$ & 3.9 & 10.6 & 50 & 0 \\
\hline $\mathrm{Bt3}$ & $42-57$ & 5YR 4/4 & 35 & 22 & 43 & $\mathrm{~K}, \mathrm{~S}, \mathrm{M}$ & 3.7 & 20.3 & 68 & 0 \\
\hline Btqm & $57-61$ & $2.5 Y R 3 / 4$ & 77 & 13 & 10 & $\mathrm{~K}, \mathrm{~S}, \mathrm{M}$ & 3.9 & 13.4 & 44 & 0 \\
\hline $\mathrm{BCt}$ & $61-71$ & $2.5 Y R 3 / 6$ & 54 & 23 & 23 & $\mathrm{~K}, \mathrm{~S}$ & 4.1 & 15.9 & 49 & 5 \\
\hline \multicolumn{11}{|l|}{ Region 5} \\
\hline Ap1 & $0-4$ & 10YR 3/2 & 74 & 13 & 13 & $\mathrm{~S}, \mathrm{~K}(\mathrm{tr})$ & 6.2 & 13.2 & 512 & 0 \\
\hline Ap2 & $4-11$ & 10YR $3 / 2$ & 53 & 32 & 15 & $\mathrm{~S}, \mathrm{~K}(\mathrm{tr})$ & 5.7 & 13.9 & 281 & 0 \\
\hline Bt1 & $11-16$ & 10YR 4/2 & 57 & 28 & 15 & $\mathrm{~S}, \mathrm{~K}(\mathrm{tr})$ & 5.6 & 19.1 & 318 & 0 \\
\hline $\mathrm{Bt} 2$ & $16-24$ & 10YR 4/2 & 33 & 51 & 16 & $\mathrm{~S}, \mathrm{~K}(\mathrm{tr})$ & 5.7 & 17.1 & 272 & 0 \\
\hline $\mathrm{C} / \mathrm{Cr}$ & $24-27$ & 10YR 4/2 & 74 & 11 & 15 & $\mathrm{~S}, \mathrm{~K}(\mathrm{tr})$ & 5.8 & 17.7 & 216 & 0 \\
\hline $\mathrm{R}$ & 27 & nd & nd & nd & nd & nd & nd & nd & nd & 0 \\
\hline
\end{tabular}




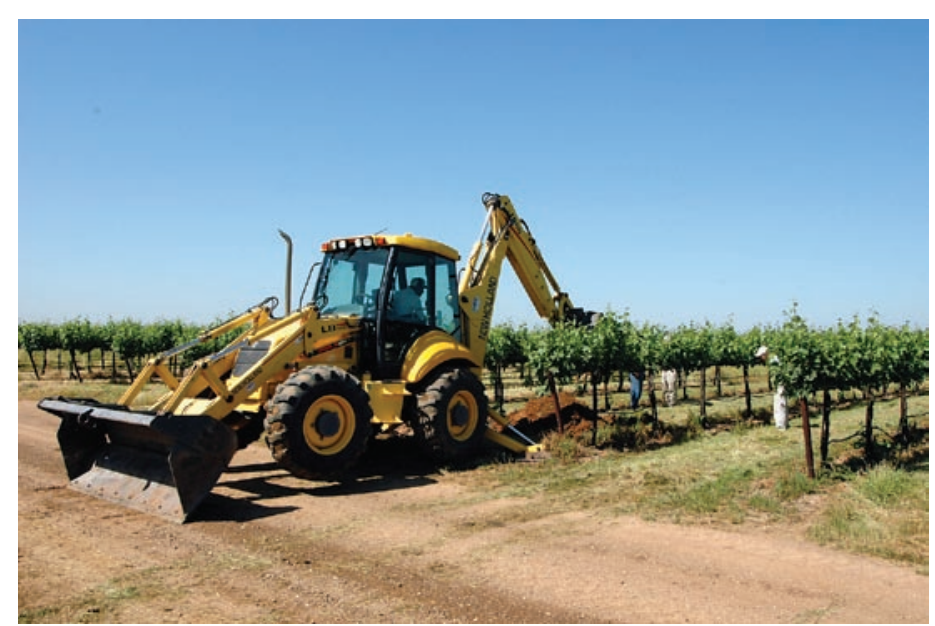

To assess the potassium status of different soils, the authors took soil samples throughout the Lodi Winegrape District to reveal differences in parent materials and degree of soil development.

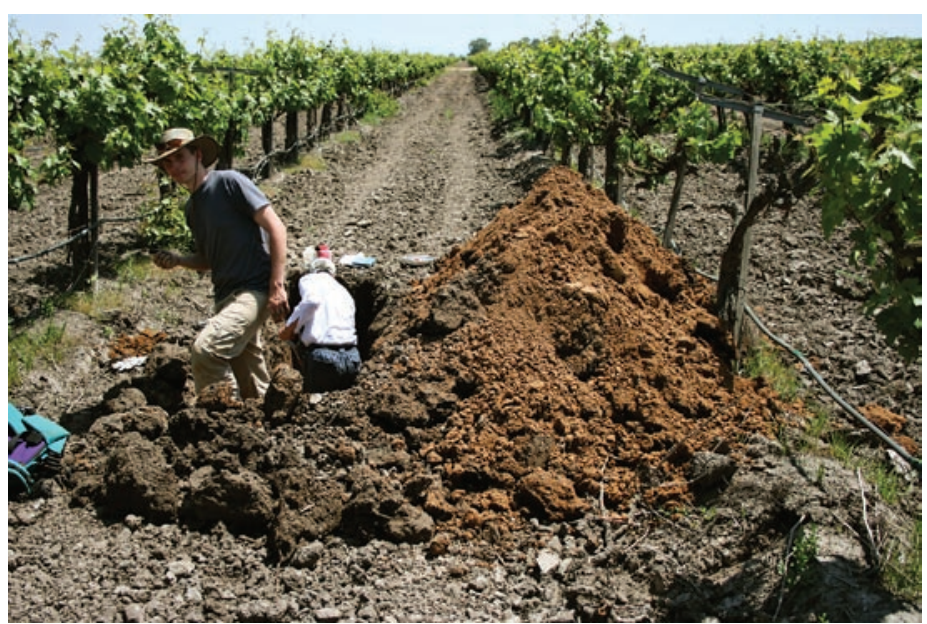

Characterization of soil profiles provided the basis to divide the District into five soil regions, by integrating the existing soil databases in a GIS and linking soil properties to potassium status. tion and exchangeable potassium were measured from soil samples collected from the horizons of each soil profile (Murashkina et al. 2007a). Samples were also analyzed for particle size distribution, $\mathrm{pH}$, cation exchange capacity and clay mineralogy.

Region 1. This region's basin alluvium soils are up to 14,000 years old, making them the youngest geologic formation. Much of this soilscape surrounds the margin of the Calaveras River alluvial fan in the south-central portion of the district in San Joaquin County, and smaller patches are present in depressions throughout Sacramento County (fig. 1). Dominant soil series in the region are Stockton, Jacktone, Galt and Hollenbeck.

A typical soil profile in region 1 has four horizons. The cultivated surface layer (Ap) is underlain by two clayrich horizons with high shrink-swell capacity (Btss1 and Btss2) (table 2). The deepest horizon (2BC) shows that basin alluvium overlies an older and more weathered parent material, as indicated by its redder color relative to overlying soil. Cation exchange capacity was high and $\mathrm{pH}$ was slightly acidic. The clay fraction was dominated by smectite in the first two horizons (Ap and Btss1). A mixture of vermiculite and smectite was found in the two deepest horizons (Btss2 and 2BC).

Exchangeable potassium, a plantavailable form, decreased with depth but was high throughout the profile, except in the 2BC horizon. High exchangeable potassium (631 milligrams potassium per kilogram of soil) in the surface horizon (Ap) is likely due to fertilization. Potassium fixation was detected in all horizons except the surface layer. Subsoil layers (Btss2 and 2BC) fixed high amounts of potassium. Fixation was highest in the horizon that contained vermiculite (2BC), suggesting that the thickness of basin alluvium overlying other alluvial deposits must be verified to accurately determine potassium response. In many instances basin alluvium covers older, buried soils (similar to soils of region 3) derived from granitic alluvium that contain high amounts of vermiculite, which fixes potassium.

Exchangeable and fixed potassium were both high in region 1 (table 2). Although high exchangeable potassium was expected, high potassium fixation was surprising because smectite-rich soils generally do not fix this nutrient. However, even though the clay fraction was dominated by smectite, there appears to be enough vermiculite in the subsoil to fix potassium. It is also possible that the silt and fine sand fractions contain vermiculite and therefore fix potassium, as found in soils elsewhere in the San Joaquin Valley (Murashkina et al. 2007b).

Soil variability within this landscape is low, but variability in the thickness of basin alluvium may be high as a function of distance from the alluvium source.

Region 2. This region consists of post-Modesto-age alluvium, which was deposited from 70,000 years ago to the present along the basin margin.
Stringers of this material extend into other parts of the district as flood plains and terraces along streams and rivers.

Large expanses of this region exist as fan deposits of the Mokelumne, Cosumnes and Calaveras rivers (fig. 1). The alluvium of the Mokelumne and Cosumnes rivers is predominantly coarse-textured, whereas that of the Calaveras River is loamy or silty. Dominant soils of region 2 are Tokay, Kingdon, Acampo, Columbia and Tujunga.

A typical soil profile in region 2 has six horizons. The surface horizons Ap, $\mathrm{A}$ and $\mathrm{AB}$ are underlain by $\mathrm{Bt}$ horizons with a slight clay accumulation (Bt1 and Bt2), then by a more or less unweathered parent material horizon (C) (table 2). The soil was coarse-textured, and clay content was low throughout the profile. Cation exchange capacity was low due to the low clay content, and $\mathrm{pH}$ was moderately acidic (table 2). The

\section{We propose that the key characteristics of soils that control potassium supply and retention can be inferred from soil-survey database information.}

clay fraction was dominantly mica with trace amounts of kaolinite. Traces of vermiculite were present in the bottom two horizons (Bt2 and C).

Exchangeable potassium was high in the surface layers and decreased substantially with depth (table 2). The top four horizons did not fix potassium. The bottom two horizons (Bt2 and C) did fix this nutrient, as much as 425 milligrams potassium per kilogram of soil, due to the presence of vermiculite. 

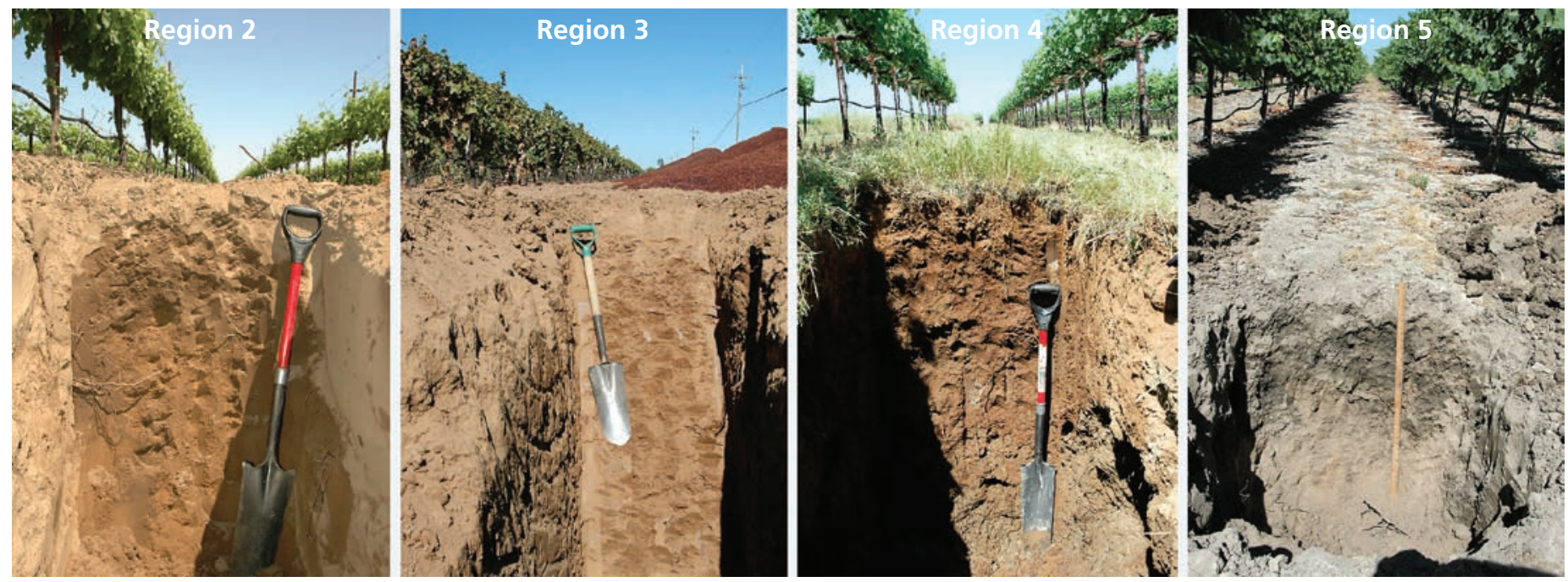

Region 2 soils formed from coarse, textured alluvium deposited during the last 70,000 years; region 3 soils, with duripans and clay-rich horizons, formed from granitic alluvium deposited 130,000 to 330,000 years ago; region 4 soils formed from alluvium deposited over 600,000 years ago, originating from metamorphosed volcanic and sedimentary rock; and region 5 soils formed from consolidated volcanic mudflows deposited 3 to 10 million years ago. In region 1 (not shown), soils develop from basin alluvium deposited over the last 14,000 years.

Region 3. This region consists of low terraces of Riverbank age, deposited approximately 130,000 to 330,000 years ago. Large expanses of this soilscape are located in the district's central portion (fig. 1). The original landscape consisted of gently undulating microtopography (highs and lows with 5- to 10-foot spacing). Leveling and cultivation have extensively altered this landscape. Soils have formed from granitic alluvium and often contain duripans (silica-cemented hardpan) and clay-rich layers that restrict water and root penetration. Dominant soils of this region are San Joaquin, Bruella, Montpellier and Cometa.

A typical region 3 soil profile has seven horizons. Surface layers (Ap and $\mathrm{BA}$ ) are underlain by clay-rich horizons (Bt1, Bt2 and Bt3) that overlie a fractured duripan (Btqm) and uncemented, slightly weathered parent material (2BC) (table 2). The duripan was shattered by deep tillage prior to the planting of vines. Clay mineralogy of the top horizon (Ap) consists of kaolinite, mica and vermiculite. Cation exchange capacity was low throughout the profile, likely due to the presence of kaolinite clay. The $\mathrm{pH}$ was slightly acidic to neutral.

Potassium fixation was high throughout the profile because soils have weathered to an intermediate degree that favors the formation of vermiculite (table 2). Exchangeable potassium was high in the topsoil, presumably due to fertilization. Low levels of exchangeable potassium in the subsoil were due to a combination of limited leaching, low cation exchange capacity (a limited ability to retain potassium from the bulk soil solution) and potassium fixation by the vermiculite.

Region 4. This region consists of dissected high terraces of Turlock Lake and Laguna age, deposited more than 600,000 years ago. The soilscape is located in the district's eastern portion (fig. 1). Soils have formed from mixed alluvium, mostly from metamorphosed volcanic and sedimentary rock, that once comprised the outer "shell" of the Sierra Nevada and have since eroded away to expose the granitic interior. The soils contain duripans and/or clay pans, but most of these were ripped before planting. The landscape was once a large alluvial fan that has since been dissected by streams and rivers into high terraces (remnant islands) of ancient soils. Some soils in this landscape cap the consolidated volcanic mudflow landscape of region 5. Dominant soils are Redding, Red Bluff and Corning.

A typical region 4 soil profile has seven horizons (table 2). Clay content increased with depth to over $40 \%$ in the third and fourth horizons (Bt1 and Bt2). A fractured duripan (Btqm) was present in the subsoil. Cation exchange capacity was relatively low in all horizons except Bt3. The $\mathrm{pH}$ was very low and decreased with depth from moderately acidic in the surface horizon (Ap) to extremely acidic in horizons below (table 2). The mineralogy of the clay fraction was dominantly kaolinite. Compared to regions 1, 2 and 3 , the soil parent material in region 4 contains less mica. In addition, the soils are intensely weathered, to the point where any initial vermiculite has been altered to kaolinite in the clay fraction.

Exchangeable potassium was high in the surface horizon (Ap) and decreased to levels as low as 44 milligrams per kilogram of soil in the subsoil. Low exchangeable potassium in the subsoil indicates that deep leaching of potassium fertilizer is minimal, or that clays with low cation exchange capacity do not retain much leachable potassium. Furthermore, the low $\mathrm{pH}$ values suggest that aluminum may occupy a substantial portion of the cation exchange capacity. No potassium fixation was observed, which was expected, because kaolinite does not fix this nutrient (table 2). Kaolinite has a low net negative charge, so potassium is not strongly adsorbed between its layers. Thus, both cation exchange capacity and potassium fixation potential are low.

Region 5. This region is the oldest geologic formation in the district, consisting of volcanic mudflows mainly of andesitic (intermediate in composition between basalt and granite) lithology deposited about 3 to 10 million years ago. Region 5 is limited to the district's eastern edge (fig. 1). The rock has been uplifted over time with the corresponding uplift of the 
Sierra Nevada, and as a result has been dissected by erosive forces. The rolling hills of this landscape are remnants of what was once locally a continuous ancient surface. The complex, undulating terrain makes these landscapes highly erodible, and erosion outpaces soilforming processes. Thus, although the parent material is quite old, the soils are relatively young and weakly developed. Typical soils occurring in this region are Pentz, Peters, Pardee and Keyes.

A typical region 5 soil profile has six horizons. The surface layers (Ap1 and Ap2) are underlain by horizons with a slight clay accumulation (Bt1 and Bt2), and then by volcanic bedrock (C/Cr and R) (table 2). Soil textures are mostly sandy loams with clay contents between $13 \%$ and $16 \%$ throughout the profile. Cation exchange capacity was highest in the Bt1 horizon where exchangeable potassium was also highest. The $\mathrm{pH}$ ranged from slightly to moderately acidic. Mineralogy of the clay fraction was dominated by smectite with trace amounts of kaolinite.

Exchangeable potassium was very high throughout the profile. These high levels are likely due to the leaching of potassium fertilizer into subsoil horizons as well as the natural supply of potassium from the weathering of volcanic rock. None of the horizons fixed potassium, because vermiculite was not present in the clay fraction (table 2). These andesitic parent materials weather rapidly and supply potassium as the primary minerals decompose.

The andesite lacks mica, therefore vermiculite does not form and potassium fixation is low.

\section{Fine-tuning the model}

While regions 1 and 5 share similar potassium supply characteristics (table 1 ), they are in separate management zones because their parent material, topography, soil depth and soil texture differ greatly. The soil profiles characterized for regions 3, 4 and 5 corresponded well with the potassium supply predicted by our model. However, in regions 1 and 2, measured potassium fixation did not fully match the model (tables 1 and 2). The thickness of recent alluvium is a variable that must be addressed. In both of these regions, vermiculite was detected in the subsoils but not in overlying strata. These landscapes represent the most recent and active sediment-deposition zones, and these sediments apparently overlie older or more weathered soils.

The thickness of recent alluvium is likely a function of the proximity to its source (a stream or river). Also, contrasts in the mineralogy of alluvium from the Mokelumne and Cosumnes rivers (dominantly granitic) versus the Calaveras River (metamorphosed sedimentary and volcanic) may have a strong influence on soil potassium behavior in regions 1 and 2 .

There are also limitations in the use of soil survey information. The level of detail in mapping (map unit delineation intensity) can differ across a soil survey area based on intended land uses. For example, the detail of soil mapping and intensity of investigation in Sacramento and San Joaquin counties was much higher in traditional agricultural areas, such as region 2, than in regions 4 and 5. At the time of mapping (mid-1970s to mid-1980s), these latter regions were mostly rangeland, a lower intensity of agricultural use. As a result, a great detail of soil variation was disregarded during mapping. These lands are now prime locations for vineyards, but mapping intensity in regions 4 and 5 may not capture important soil variation for wine-grape production. In contrast, soil mapping in region 2 may be more detailed than needed for wine-grape production, but could have large im- pacts on other potential land uses such as riparian restoration, septic-tank suitability or urban development.

Nonetheless, this research demonstrates the utility of combining soil survey information with limited ground-truthing to develop nutrient management regions for wine-grape production. Our model delineates five potassium-management regions based on the nature of parent material and degree of soil development. These five regions stratify the landscape of the Lodi Winegrape District into distinct soilscapes. Each nutrient management region has a unique combination of native potassium supply, exchangeable potassium and potassium fixation potential. The model will serve as a foundation to address a variety of nutrient management strategies and best management practices. Our current research is aimed at refining this model and documenting the degree of soil variability within each region.

A.T. O'Geen and S. Pettygrove are Cooperative Extension Soils Specialists, $R$. Southard is Professor, and H. Minoshima is Graduate Student, Department of Land, Air and Water Resources, UC Davis; and P.S. Verdegaal is Cooperative Extension Advisor, UC Cooperative Extension, San Joaquin County. The authors gratefully acknowledge research funding from the Lodi Winegrape Commission as well as the multiple landowners and vineyard managers who provided field support and access to sites. We also thank Jiayou Deng, Tony Orozco and Chuck Ingels for their support in the field and laboratory.

\section{References}

Boulton R. 1980. A hypothesis for the presence, activity, and role of potassium/hydrogen, adenosine triphosphatases in grapevines. Am J Enol Viticult 31(3):283-7.

Christensen LP, Kasamatis AN, Jensen FL. 1978. Grapevine nutrition and fertilization in the San Joaquin Valley. UC ANR Pub 4087 Oakland, CA. $41 \mathrm{p}$.

Krstic M, Moulds G, Panagiotopoulos B, West S. 2003. Growing Quality Grapes to Winery Specifications. Adelaide, Australia: Winetitles.

Marchand DE, Allwardt A. 1981. Late Cenozoic stratigraphic units, northeastern San Joaquin Valley, California. US Geological Survey Bulletin 1470.

Murashkina MA, Southard RJ, Pettygrove GS. 2007a. Potassium fixation in San Joaquin Valley soils derived from granitic and nongranitic alluvium. Soil Sci Soc Am J 71:125-32.
Murashkina MA, Southard RJ, Pettygrove GS. 2007b. Silt and fine sand fractions dominate $K$ fixation in soils derived from granitic alluvium of the San Joaquin Valley, California. Geoderma 141:283-93.

Schoeneberger PJ, Wysocki DA, Benham EC, et al. 2002. Field book for describing and sampling soils, version 2.0. Natural Resources Conservation Service, National Soil Survey Center. Lincoln, NE.

Soil Survey Staff. 1999. Soil Taxonomy - A basic system of soil classification for making and interpreting soil surveys ( 2 nd ed.). USDA-NRCS Agricultural Handbook No 436. US Government Printing Office. Washington, DC. 869 p

Wehmeier GH. 2002. Use of decision tree analysis to evaluate the effects of viticultural variables on wine chemistry. MS thesis. UC Davis Department of Food Science. $174 \mathrm{p}$ 